\title{
Government Price Regulation of Pharmaceuticals in Slovakia and the United States
}

\author{
M. M. Costello (Michael M. Costello)
}

The University of Scranton, USA

Original Article

\section{E-mail address:}

michael.costello@scranton.edu

\section{Reprint address:}

Michael M. Costello

The University of Scranton

$4^{\text {th }}$ Floor McGurrin Hall

Scranton, PA 18510-4699

USA

Source: Clinical Social Work and Health Intervention

Pages: $21-24$

Volume: 9

Issue: 1

\section{Reviewers:}

Roberto Cauda

Institute of Infectious Diseases, Catholic University of the Sacred Heart, Rome, IT

Gunther Dorfmeister

Vienna General Hospital, Vienna, AT

\section{Key words:}

Price. Pharmaceuticals. Government. Slovakia. United States. Health Reform.

\section{Publisher:}

International Society of Applied Preventive Medicine i-gap

CSWHI 2018; 9(1): 21 - 24; DOI 10.22359/cswhi_9_1_03 @ 2018 Clinical Social Work and Health Intervention

\section{Abstract:}

Health reform is a topic of significant interest to national governments. The need to assure health care access to national populations at reasonable cost compels governments to explore various means of restraining cost increases. Government price regulation, effectiveness research and cross-border re-importation are accepted practice in Slovakia, but prohibited by statute and regulation in the United States. 


\section{Introduction}

Government policy-makers have many options to use when seeking to rein-in escalating health care costs. Expanding national health budgets; increasing private insurance premiums; and growing provider costs merge together to stir concern for many national leaders who worry that price and cost increases in the healthcare sector may jeopardize the overall performance of their national economies.

One glaring target for controlling a nation's health care costs is pharmaceuticals. Large national and international drug manufacturers seek to expand their product markets by selling pharmaceuticals worldwide. In many instances, those marketing efforts lead to increased levels of inter-firm competition amenable to specific price regulation tactics.

Slovakia has positioned itself to take advantage of certain progressive price regulation tools available to national governments. This ability is further enhanced by Slovakia's health economy.

...pharmaceuticals play an important role in Slovakia's (health) expenditure.

Although health spending is well below the OECD average when considered as a share of GDP $-6 \%$ in Slovakia compared to $9 \%$ across the OECD in 2005 - Slovakia's pharmaceutical expenditure accounts for a relatively high portion of health spending (nearly double the OECD average share at $32 \%$ of spending) and more than $2 \%$ of the country's income. (OECD 2008, p.8)

By comparison, pharmaceutical prices are much higher in the U. S., but the nation has not taken any aggressive approach at the federal government level to stabilize pharmaceutical prices. In 2012, the OECD indicated that U. S. pharmaceutical expenditures per capita were more than double the OECD average for the same period of time (OECD 2014, p.3).

\section{Aggressive Price Regulation}

In examining Slovak pharmaceutical pricing policies, three noteworthy considerations stand out in comparison to U. S. drug pricing policy. 1) In Slovakia, the government sets retail pharmacy prices and ex-factory prices for prescription drugs sold for use in Slovak hospitals. 2) Government regulators make use of reference pricing and effectiveness research in determining the categorization of pharmaceuticals subject to such price controls. 3) The government also allows the re-importation of drugs if there is a potential price advantage (Costello, 2017). In contrast, the U. S. Government is prohibited from negotiating pharmaceutical prices and for using government - financed effectiveness research for coverage, reimbursement or treatment decisions. U. S. Federal Regulations also prohibit the re-importation of pharmaceuticals.

According to OECD, the Slovak Ministry of Health "determines the maximum retail price for reimbursed pharmaceutical products and the maximum manufacturer's price for in-hospital pharmaceutical products (OECD 2008, p.14). Slovak National Policy is also influenced by European Union Policy which allows for "re-importation" of pharmaceuticals from one EU nation to the other in order to take advantage of more favorable pricing in the exporting nation. Pharmaceuticals imported into Slovakia are ultimately regulated as to retail price, but the price threshold is determined by reference to ex-factory prices in 9 selected European Nations including "the country of manufacture, Austria, France, Germany, 
Italy, Spain, the Czech Republic, Hungary and Poland. (OECD 2008, p. 14)"

Reference pricing is used to compare the prices of comparable pharmaceuticals in order to establish the pricing of a new market entrant. The referenced prices are used to justify the applicable price of the new product.

Effectiveness studies influence the decisions as to which medications will be price-regulated for reimbursement. Slovak Government Officials examine a number of effectiveness measures in making reimbursement decisions for pharmaceuticals on the "positive lists".

A pharmaceutical is eligible to be included on the positive list, and consequently reimbursed, if there is sufficient clinical evidence of its effectiveness and capacity to save life, to cure diseases, to prevent the onset of serious health complications, to prevent deterioration of the severity of a disease or its transition to a chronic state, to serve as an active prophylaxis, or to mitigate the symptoms of disease (OECD 2008, p.17).

While U.S. Law allows private insurance companies and certain public state programs to set pricing for reimbursement of drugs, the U. S. Government itself does not set pharmaceutical prices for reimbursement purposes; prohibits by regulation the re-importation of pharmaceuticals from lower price-advantaged international markets; forbids the use of government subsidized effectiveness research for setting reimbursement levels.

The U.S. has a long history of avoiding government price setting in competitive markets. Rather, traditional economic thinking says that competitive markets, subject to the laws of supply and demand, will establish appropriate prices. However, the noted price inelasticity of many prescription medications would seem to cast some doubt on this line of economic reasoning. Nemec (2013) suggests that Slovaks may be more amenable to government efforts to establish pricing for prescription pharmaceuticals.

The approaches of all actors influencing health care reforms and trends mirror societal values of European Union members. The heritage of the Socialist period remains viable as citizens prefer to rely on "state" help rather than develop individual responsibility for their welfare (p. 196).

In the U.S., federal law prohibits the government from negotiating drug prices directly with pharmaceutical firms. The Medicare Modernization Act, which established the Medicare Pat D prescription drug benefit in 2006, established the prohibition (Feldstein 2015, p.462).

While effectiveness studies have become widely used in Slovakia and other European nations, the use of such studies, known as comparative effectiveness research (CER), is prohibited in the United States by the Patient Protection and Affordable Care Act (Obamacare), enacted in 2010. Despite the fact that the act allocated $\$ 1.1$ billion for CER, the U. S. Congress prohibited the use of research information from CER for "mandating coverage, reimbursement or treatment decisions for public and private payers" (ibid p.347).

Likewise, re-importation is permitted among European Union Nations as a way of taking advantage of the most favorable pharmaceutical pricing in the EU. However, re-importation is prohibited by regulation of the U.S. Food and Drug Administration (FDA), even though the U.S. Congress had authorized it (Costello 2017, p.45). The U.S. FDA reported to Congress that it did not have the ability to assure the safety of pharmaceuticals reimported back to the United States. 


\section{Conclusion}

Slovakia has utilized pharmaceutical pricing regulation, effectiveness studies, and importation from other nations as means of stabilizing pharmaceutical prices within its national borders. Of note, is the fact that the U.S. has been prohibited by federal statute and regulation from using any of these three price-restraining tools with the result that the U.S. Government reimburses public insurance beneficiaries use of these drugs at higher prices than would be the case if Slovak price regulation mechanisms were in use.

\section{Resume}

Mr. Costello is a full time faculty member in the Department of Health Administration and Human Resources at The University of Pennsylvania Scranton, U.S.A. where he also serves as Assistant Program Director for an accredited online MHA degree. Scranton's on-campus and online MHA program enrollments combine to make it the largest program in the United States. He has held faculty appointments at St. Elizabeth University in Bratislava and Trnava University, both in the Slovak Republic.

\section{References}

1. COSTEllo, M (2017) Regulating Pharmaceutical Pricing: Why is Europe More Aggressive Than the U.S.? The Journal of International Management Studies. 12(1) February.
2. FELDSTEIN, P (2015) Health Policy Issues: An Economic Perspective. Sixth Edition. Chicago, IL: HAP/AUPHA.

3. FIALOVA T, SVESTKOVA O, RODOVA Z (2017) Static Progressive Stretching in Patients with Spasticity of the Upper Leg After Cerebral Stroke. Rehabilitation, 2017, Vol. 54, No. 4, ISSN0375-0922, pp. 273278.

4. CHLUMSKY M, DADOVA K (2017) Senior Fitness Testing in Senior Fitness Test. Rehabilitation, 2017, Vol. 54, No. 4, ISSN0375-0922, pp. 259-272.

5. NEMEC, J (2013) Health Reforms in Slovakia. Health Reforms in Central and Eastern Europe Bjorkman and Nemec (eds). The Hague, Netherlands, Eleven International Publishing.

6. ORGANIZATION FOR ECONOMIC COOPERATION AND DEVELOPMENT (2008) Pharmaceutical Pricing and Reimbursement Policies in Slovakia. OECD Health Working Papers 31.

7. ORGANIZATION FOR ECONOMIC COOPERATION AND DEVELOPMENT (2014) OECD Health Statistics 2014. How Does the United States Compare? www. oecd.org/unitedstates. Retrieved January 26, 2017.

8. VAVRECKOVA V (2005) Practice and Supervision in Professional Practice. Faculty of Education, Catholic University, Ruzomberok, Department of Social Work, Ruzomberok, 2005, 48 pages, ISSN 13362232 . 